University of Nebraska - Lincoln

DigitalCommons@University of Nebraska - Lincoln

Faculty Publications, Classics and Religious

Studies Department

1998

\title{
How Archaeology Affects the Study of Texts: Reflections on the Category "Rewritten Bible" at Qumran
}

Sidnie White Crawford

University of Nebraska-Lincoln, scrawford1@unl.edu

Follow this and additional works at: https://digitalcommons.unl.edu/classicsfacpub

Part of the Classics Commons

Crawford, Sidnie White, "How Archaeology Affects the Study of Texts: Reflections on the Category "Rewritten Bible" at Qumran" (1998). Faculty Publications, Classics and Religious Studies Department. 90. https://digitalcommons.unl.edu/classicsfacpub/90

This Article is brought to you for free and open access by the Classics and Religious Studies at DigitalCommons@University of Nebraska - Lincoln. It has been accepted for inclusion in Faculty Publications, Classics and Religious Studies Department by an authorized administrator of DigitalCommons@University of Nebraska - Lincoln. 


\section{How Archaeology Affects the Study of Texts Reflections on the Category "Rewritten Bible" at Qumran}

\section{Sidnie White Crawford}

I $n$ recent years, as scholars have begun the long overdue reinvestigation of the archaeology of Khirbet Qumran, the complaint has often been heard that the existence of the texts from the eleven caves surrounding the site of Qumran has affected the archaeological interpretation of the ruins. Would Roland de Vaux, the excavator of Qumran, have identified the ruins as a communal settlement of a particular group of Jews, the Essenes, if he had not been aware of the contents of the scrolls, especially documents such as the Rule of the Community? The question is rhetorical; the answer, of course, is no. Thus, Pauline DonceelVoûte can say, "with the finding of the scrolls, Qumran archaeology just seems to have stopped." I am happy to

$1 \quad$ P. Donceel-Voûte, "The Archaeology of Khirbet Qumran," in Methods of Investigation of the Dead Sea Scrolls and the Khirbet Qumran Site: Present Realities and Future Prospects, M. O. Wise, N. Golb, J. Collins and D. Pardee, eds., (New York: New York Academy of Sciences, 1994) p. 34. 
report that this is no longer true and that there have been many exciting and thought-provoking studies of Qumran archaeology recently, illustrated by the popularity of the archaeology sections at the Jerusalem Dead Sea Scrolls Congress in July, 1997. ${ }^{2}$

However, I would like to approach the relationship of archaeology and texts from a slightly different angle. While the discovery of the texts may have affected the interpretation of the archaeology, it is equally true that the archaeology affected the interpretation of the texts. That is, once de Vaux had identified Qumran as an Essene settlement, and especially once he had identified one of the loci (locus 30) as a "scriptorium" where scrolls were copied, the scrolls were identified as an Essene library. ${ }^{3}$ This influenced our understanding of the texts in this way: if the library was the collection of a particular sect, living in isolation in the desert, then the texts were not representative of a wider Judaism of the period. Now, this reasoning did not have much impact on the biblical texts, or even the previously known apocryphal and pseudepigraphical texts, which were obviously known and preserved outside of Qumran. It is the previously unknown non-biblical texts that were most heavily affected by this reasoning. They were unknown prior to the discovery of the scrolls and they were found in the eleven caves associated with Qumran; hence they must be Essene compositions, copied or even composed at Qumran. Thus, they were scrutinized for what they might say about Essenes, but not about Judaism in general (as if the two were completely separate!). So Frank Moore Cross

2 See the forthcoming volume, The Dead Sea Scrolls-Fifty Years After Their Discovery: Proceedings of the Jerusalem Congress, July 10-25, 1997, L. H. Schiffman, E. Tov and J. VanderKam, eds., (Jerusalem: Israel Exploration Society, forthcoming).

3 R. de Vaux, Archaeology and the Dead Sea Scrolls (London: Oxford University Press, 1973), especially the section entitled "The Ruins and the Texts." 
could say "in [the Cave 4] texts we find a cross section of the literature of sectarian Judaism at the end of the preChristian era." ${ }^{4}$ Now, however, few scholars would accept that statement. The present consensus, as much as there is ever a consensus in Qumran studies, would run something like this: the best archaeological evidence suggests that Qumran was a community settlement of Jews in the first century BCE and first century CE. The scrolls found in the eleven caves in the approximate vicinity of Qumran belonged to the settlement, and can be understood as a collection. However, the majority of the texts were neither composed at Qumran nor copied there, and many of them are part of the general Jewish literature of the period, rather than representative of narrow Qumran sectarian thought. ${ }^{5}$ One group of Qumran texts affected by this reevaluation of the relationship of the texts to the site is the "Rewritten Bible" texts.

The category "Rewritten Bible" has been rather loosely defined, but the criteria for membership in this category include a close attachment, either through narrative or themes, to some book contained in the present Jewish canon of Scripture, and some type of reworking, whether through rearrangement, conflation, or supplementation, of the present canonical biblical text. ${ }^{6}$ Thus, works such as Pseudo-Ezekiel or Pseudo-Daniel would be excluded from the category, since, although thematically related to a biblical text (Ezekiel, Daniel), they do not reuse the actual biblical text. There are three large texts from Qumran which do fit this rather loose definition: 4QReworked Pentateuch,

4 F. M. Cross, The Ancient Library of Qumran $\mathcal{E}^{\circ}$ Modern Biblical Studies, rev. ed., (Grand Rapids, MI: Baker Book House, 1961) p. 35 [italics mine].

5 See, e.g., J. VanderKam, The Dead Sea Scrolls Today (Grand Rapids, MI: Eerdmans, 1994) for a book length discussion of this general hypothesis.

6 Cf. G. Vermes, "Bible Interpretation at Qumran," in Eretz Israel 20 (1989) pp. 185-88. 
Jubilees, and the Temple Scroll. A fourth text, the Genesis Apocryphon, also may fit this category, although, since it is in Aramaic, it is a translation as well as a rewriting. ${ }^{7}$ In this paper I will investigate the three large texts and their relationship to one another. First, $4 \mathrm{QReworked} \mathrm{Pentateuch.}$

\section{QReworked Pentateuch}

4QReworked Pentateuch (4QRP) appears in five manuscripts from Qumran Cave 4: 4Q158, 4Q364, 4Q365, 4Q366 and 4Q367. ${ }^{8}$ The manuscripts preserve portions of the Torah from Genesis through Deuteronomy. As Emanuel Tov has stated in the editio princeps, the base text, where it can be determined for 4Q364 and probably $4 \mathrm{Q} 365$, was the proto-Samaritan text (that is, the recension of the Torah which is preserved, with minor ideological changes, in the Samaritan Pentateuch), ${ }^{9}$ but $4 \mathrm{QRP}$ is characterized by further reworkings of the text, most notably the regrouping of passages, often, but not always, according to a common theme and by the addition of previously unknown material into the text. Two examples will suffice:

7 Other small texts may belong to this category as well, such as $4 \mathrm{QParaphrase}$ on Genesis and Exodus, and the pseudo-Jeremiah manuscripts.

8 J. M. Allegro, "Qumran Cave 4: I (4Q158-4Q186)" in Discoveries in the Judaean Desert V (Oxford: Clarendon, 1968) pp. 1-6; plate 1. E. Tov and S. White, "Reworked Pentateuch," in Discoveries in the Judaean Desert XIII (Oxford: Clarendon, 1994) 187-352, pls. XIII-XXXVI. M. Segal has recently argued that 4 Q158 should not be classified as a manuscript of $4 \mathrm{QRP}$, but as a separate composition. See his forthcoming paper, "4QReworked Pentateuch or 4QPentateuch?" in The Dead Sea Scrolls-Fifty Years After Their Discovery. I have not yet been able to study his argument in detail. However, the five manuscripts presently classified as 4 QRP certainly represent the same type of composition/redaction.

9 E. Tov, DJD 8, pp. 192-96. 
in 4 Q367, frags. 2a-b, the following pericopes are grouped together: Lev 15:14-15; 19:1-4, 9-15.

...to the opening of the t[ent of meeting, and he will give them to the priest. (15) And the priest will make one] sin-offering and one burnt-offering, [and the priest will atone for him before the Lord for his flux. (19:1) And] the Lord [spoke] to Moses, say[ing, (2) "Speak to all the congregation of the children of Israel, and] say to them, [You will be holy, for I, the Lord you]r[ God am holy.] (3) A man [will fear] his mother[ and his father, and my Sabbath you will observe; I am the Lord] your[ G]o[d.] (4) Do not t[urn to idols and molten gods do not make for yourselves; I am the Lord yo]ur[ God.] (9) [And when you reap the harvest of your land, do not harvest com]pl[etely the border of ] your field, [ and do not pick the gleaning of your harvest. (10) And your vineyard do not glean, and the fallen grapes of your vineyard you must not gather] up; for the p[oor and the stranger you shall leave them; I am the Lord your God. (11) Do not steal, and do not dece]ive, and let no one l[ie to his fellow (12) or swear falsely by my name for falsehood, lest you profane ]the name of your God; [ I am the Lord. (13) Do not oppress your companion, and do not rob; do not keep] his wages until morni[ng. (14) Do not curse a deaf person or put a stumbling block before a blind one; you will fear] your [G]od; I[ am the Lord. (15) You will not make an unjust judgment; you will not raise the face of the poor nor honor] the face of the grea[t in righteousness..."

The reason for this grouping is not immediately evident, since the passages are not thematically related (other than by being legal material), and the catchphrase "I am the Lord" appears only in the last two units. It is possible that the intervening material has been moved elsewhere in the text (Lev 18:25-29 occurs in 4Q365, frag. 22), and we are left with this rather truncated text. ${ }^{10}$

10 E. Tov and S. White, DJD 8, pp. 348-49. 
An example of an addition occurs in 4Q365, frag. 23, following Lev 24:2, where at least eight additional lines of text have been inserted, which discuss festival offerings, in particular the Passover offerings and the non-biblical New Oil and Wood festivals. ${ }^{11}$

4. . . . saying, when you come to the land which

5. I am giving to you for an inheritance, and you dwell upon it securely, you will bring wood for a burnt offering and for all the wo[r]k of

6. [the H] ouse which you will build for me in the land, to arrange it upon the altar of burnt-offering, and the calv[es

7. ] for Passover sacrifices and for whole burnt-offerings and for thank offerings and for free-will offerings and for burnt-offerings, daily [

8. ] and for the doors and for all the work of the House the[y] (or: he) will br[ing

9. ] the [fe]stival (or appointed time) of fresh oil. They will bring wood two [by two

10. ] the ones who bring on the fir[st] day, Levi [

11. Reu]ben and Simeon and [on t] he fou[rth] day [

In neither case, nor in any of the other reworkings of the biblical text, is there any scribal indication that this is changed or new material. ${ }^{12}$ As Michael Fishbane has noted for the phenomenon generally, in texts containing innerbiblical exegesis, there is no clear separation between lemmas and commentary. ${ }^{13}$ In fact, for the second example given above, the terms "lemma" and "commentary" are misleading, for the additional material in frag. 23 in no way comments on the preceding "biblical" verses, but simply

11 E. Tov and S. White, DJD 8, pp. 290-96.

12 Of course, all five manuscripts are fragmentary, so this claim is not absolutely certain.

13 M. Fishbane, Biblical Interpretation in Ancient Israel (Oxford: Clarendon, 1985) p. 12. 
inserts new text, presumably to give these new festivals of Oil and Wood the same force of Mosaic authority as other festivals. Therefore, it seems clear that the reader of this text was expected to view it as a text of the Pentateuch, not a "changed Pentateuch," or a "Pentateuch plus additions." In other words, if one were to place 4QReworked Pentateuch on a continuum of pentateuchal texts, the low end of the continuum would contain the shorter, unexpanded texts such as 4 QDeut; ${ }^{\mathrm{g}}$; next would be a text such as $4 \mathrm{QExod}^{\mathrm{a}}$; next the expanded texts in the proto-Samaritan tradition such as 4 QpaleoExod ${ }^{\mathrm{m}}$ and $4 Q \mathrm{QNum}^{\mathrm{b}}$, as well as other expanded texts not necessarily in the protoSamaritan tradition; and then finally the most expanded text of all, 4QReworked Pentateuch. ${ }^{14}$

In regard to the question of whether $4 Q R P$ is sectarian, that is, peculiar to the Qumran community, the only argument in favor of this is the fact that, before its discovery in Cave 4, it was unknown in Jewish tradition. However, as is now clear, that in itself is not a sufficient argument for Qumran composition. 4QRP itself gives no internal indication of its date of composition; the earliest copy is from the first half of the second century BCE, so it must have been composed before that. Further, 4QRP shows a relationship with two texts, Jubilees and the Temple Scroll, which argue for its pre-Qumran composition. Next I shall turn to Jubilees.

\section{Jubilees}

Jubilees, which was found in fourteen or fifteen copies in five caves at Qumran, ${ }^{15}$ is an extensive reworking of Genesis 1 - Exodus 12 that presupposes and advocates the use of the 364-day solar calendar. The author of Jubilees wished

14 For a discussion of the related question of whether or not the Qumran community considered 4QRP authoritative, see my forthcoming article "The Rewritten Bible at Qumran: A Look at Three Texts," Israel Exploration Journal.

15 J. VanderKam, "The Jubilees Fragments from Qumran Cave 4" in The Madrid Qumran Congress: Proceedings of the 
to show that the solar calendar and the religious festivals and halakhah (and his particular interpretation of them) were not only given to Moses on Sinai, but were presupposed in the creation of the universe and carried out in the antediluvian and patriarchal history. ${ }^{16}$ For example, in Jubilees 6 , Noah is credited with being the first human to celebrate the festival of Shevuot. The author of Jubilees follows the chronological sequence of his base text, but rewrites it by adding extensive new material, such as the tales of Abraham's youth in chapter 12, and by condensing or omitting material (sometimes for ideological reasons), such as the rather shady story of Abraham passing his wife off as his sister, not once but twice (Gen 12:10-20, 20:2-7)! The author also adds supplementary or explanatory material to his biblical base text. The result is a text radically different from the Torah; it would be impossible for a reader familiar with both not to know that Jubilees was a new work. Jubilees differs in this regard from $4 Q R P$, which a reader might accept as a text of the Torah.

There is little doubt that Jubilees was an authoritative text for the group at Qumran that preserved it. It is cited by name in the Damascus Document (CD) 16:3-4 and probably alluded to in CD 10:8-10. It also presents itself as an authority; the fragments from Qumran make clear that Jubilees claims to be dictated by an angel of the presence to Moses. ${ }^{17}$ Thus, since the book both wishes to be seen as divinely inspired and is granted community acceptance as an authority, it is probable that Jubilees had authoritative

International Congress on the Dead Sea Scrolls, Madrid, 18-21 March 1991, vol. 2, J. Trebolle Barrera and L. Vegas Montaner, eds. (Leiden: Brill, 1992) p. 648.

16 For a convenient English translation of Jubilees, see O. S. Wintermute, "Jubilees" in The Old Testament Pseudepigrapha, vol. 2, edited by J. H. Charlesworth (New York: Doubleday, 1985) pp. 35-142.

17 J. VanderKam, "The Jubilees Fragments from Qumran Cave 4" pp. 646-47. 
status at Qumran. It is generally accepted, however, that Jubilees was not composed at Qumran, since it is dated by a majority of scholars to the middle of the second century BCE, just after the Maccabaean revolt. ${ }^{18}$ This generally accepted date may be helpful in determining 4QRP's provenance, since it is possible that in Jubilees 27 we find an allusion to 4QRP. This allusion occurs in 4Q364, frag. 3, col. 1, in the story of Jacob and Esau. 4QRP is here expanded, probably (although the text is not extant) after Gen 28:5: "And Isaac sent Jacob, and he went to Paddan Aram to Laban, the son of Bethuel the Aramean, brother of Rebekah the mother of Jacob and Esau." The expansion, for which we do not possess the beginning, concerns Rebekah's grief over the departing Jacob and Isaac's consolation of her. The text then continues with Gen 28:6.

1. him you shall see [

2. you shall see in peace [

3. your death, and to your eyes [ $\ldots$. lest I be deprived of even]

4. the two of you. And [Isaac] called [to Rebecca his wife and he told]

5. her all these wor[ds

6. after Jacob her son [ and she cried

7. And Esau saw that [

The expansion found here in 4QRP echoes a similar expansion in Jubilees 27, where Rebekah grieves after her departing son and Isaac consoles her. In 4Q364 the phrases in question are "him you shall see" (מלתו תר אה משר, 1.1), "you shall see in peace" (אים בשרום, 1.2), and "after Jacob her son" (אחר, יעקוב בנה, 1.6), which recall Jub 27:14 and 17: "the spirit of Rebecca grieved after her son," and "we see him in peace" (unfortunately, these verses are not found in the Hebrew fragments of Jubilees

18 See O. S. Wintermute, "Jubilees" pp. 43-44. 
found at Qumran $\left.{ }^{19}\right)$. Both texts also contain a reminiscence of Gen 27:45, "why should I be deprived of both of you in one day?" The passages in 4QRP and Jubilees are similar but not parallel. Is one alluding to or quoting the other? It seems possible, especially since this particular expansion does not occur in other reworked biblical texts (e.g. Pseudo-Philo). Further, it seems more likely that Jubilees is alluding to 4QRP than the other way around, since Jubilees is a much more systematic and elaborate reworking of the Pentateuch than $4 Q R P$, which has here simply expanded two biblical verses. However, it is also possible that Jubilees and $4 \mathrm{QRP}$ are both borrowing from a common fund of tradition; a similar scene occurs in Tob 5:18-22, where Tobit and Anna are bidding farewell to Tobias. The texts would then be only indirectly related. If, however, Jubilees has used $4 \mathrm{QRP}$ as a source, this would indicate that 4QRP's date of composition is earlier than the mid-second century BCE date of Jubilees, and thus it cannot be a Qumran composition. The next piece of evidence in that regard comes from the Temple Scroll.

\section{The Temple Scroll}

The Temple Scroll, found in two copies from Cave 11 and two (possible) different recensions from Cave $4,{ }^{20}$ is a reworking of parts of the biblical text from Exodus through Deuteronomy, with a clear ideology that embraces the solar

19 J. VanderKam and J. T. Milik, "Jubilees" in DJD 13, pp. $1-186$, pls. I-XII.

20 11QTemple: ${ }^{\mathrm{a}}$ Y. Yadin, The Temple Scroll, 3 vols., rev. Eng. ed. (Jerusalem: Israel Exploration Society, 1983). 11QTemple": F. García Martínez, "11QTemple: A Preliminary Publication," in The Madrid Qumran Congress: Proceedings of the International Congress on the Dead Sea Scrolls, Madrid, 18-21 March 1991, vol. 2, J. Trebolle Barrera and L. Vegas Montaner; eds. (Leiden: Brill, 1992) pp. 363-92. 4QTemple?: S. White, "4QTemple?" in DJD 13. 4Q542: E. Puech, "Fragments du plus ancien exemplaire du Rouleau 
calendar and advocates a particular interpretation of the halakhah involving purity, festivals, and the law of the king, combined with a vision of the ideal temple. The Temple Scroll has been the subject of much controversy regarding its status and function at Qumran, illustrating my earlier point about the archaeological context of the scrolls clouding the question of their place in the literature of the Second Temple. Yigael Yadin, the editor of the Temple Scroll, stated unequivocally that "it is my considered view that the Temple scroll is undoubtedly a literary and religious product of the Dead Sea Scrolls sect." ${ }^{21}$ Others have sharply disagreed with this assessment. Hartmut Stegemann, for example, states that "there is no specific connection whatsoever between the Qumran community and the composition of the text represented by the Temple Scroll." ${ }^{22}$ It is certainly true that many of the ideas found in the Temple Scroll were congenial to the Qumran community, such as the solar calendar, the festivals of new wine and new oil, and the observance of strict laws of purity. However, it lacks the isolationist tone of later sectarian documents; it rather lays out a program which "includes the whole of Israel as a homogenous entity." ${ }^{23}$ This difference makes it less likely that it was actually composed at Qumran. Further, it is certain that at least some of its sources, which include the book of Deuteronomy, were composed before the settlement at

du Temple (4Q542)" in Legal Texts and Legal Issues: Proceedings of the Second Meeting of the International Organization for Qumran Studies, Cambridge 1995, M. Bernstein, F. García Martínez, and J. Kampen, eds. (Leiden: Brill, 1997) pp. $19-66$.

21 Y. Yadin, The Temple Scroll: The Hidden Law of the Dead Sea Sect (New York: Random House, 1985) p. 234.

22 H. Stegemann, "The Literary Composition of the Temple Scroll and its Status at Qumran," in Temple Scroll Studies, G. Brooke, ed. (Sheffield: JSOT Press, 1989) pp. 127-28.

23 G. Boccaccini, Beyond the Essene Hypothesis (Grand Rapids: Eerdmans, 1998) p. 103. 
Qumran, although its final redaction may have taken place as late as the first century BCE. ${ }^{24}$ Finally, it is a matter of some doubt that the Temple Scroll carried any authoritative status at Qumran (unlike Jubilees). All of these factors indicate that the Temple Scroll is a non-Qumranic composition. $^{25}$

If the Temple Scroll is indeed a non-Qumranic composition, this is further evidence that $4 Q R P i_{\text {}}$ as well, since there is one indication in the Temple Scroll of dependence on or an allusion to $4 \mathrm{QRP}$. This occurs in 4 Q365, frag. 23, the text of which is given above, where, following Lev 24:2, the text has a long addition concerning festival offerings, including the festival of fresh oil and the wood festival, festivals also found in the Temple Scroll. In fact, as was first noted in print by Yadin, material in frag. 23 is parallel to cols. 23-24 of the Temple Scroll. ${ }^{26}$ The decisive parallel, which points to a definite relationship, is the order of the tribes bringing the wood for the Wood Festival: Levi and Judah, Benjamin and Ephraim and Manasseh, Reuben and Simeon, Issachar and Zebulon, Gad and Asher, and Dan and Naphtali, an order which occurs only here 4QRP, in

24 See A. M. Wilson and L. Wills, "Literary Sources in the Temple Scroll," HTR 75 (1982) pp. 275-288; M. Hengel, J. H. Charlesworth, M. Dayagi Mendels, "The Polemical Character of 'On Kingship' in the 'Temple Scroll'. An Attempt at Dating 11QTemple," JJS 37 (1986) pp. 28-38; M. O. Wise, A Critical Study of the Temple Scroll from Qumran Cave 11, SAOC 49 (Chicago: Oriental Institute, 1990); F. García Martínez, "Sources et rédaction du Rouleau du Temple," Henoch 13 (1991) pp. 219-232.

25 For a discussion of the enigmatic character of the Temple Scroll, see L. Schiffman, Reclaiming the Dead Sea Scrolls (Philadelphia and Jerusalem: The Jewish Publication Society, 1994) pp. 257-271.

26 Y. Yadin, The Temple Scroll, vol. 2, rev. Eng. ed. (Jerusalem: Israel Exploration Society, 1983) p. 103. 
the Temple Scroll, and nowhere else. ${ }^{27}$ The question of concern is whether one text is citing or alluding to the other. John Strugnell, the original editor of 4QRP, suggested the possibility, ${ }^{28}$ and Stegemann has argued outright that 4 QRP is a source for the Temple Scroll. ${ }^{29}$ Michael Wise believed that frag. 23, for which he did not have the context of 4QRP, was part of his "D Source" for the Temple Scroll. ${ }^{30}$ Wise, in fact, argues that the additional material in frag. 23 is "deuteronomizing," an attempt to update Leviticus by the inclusion of deuteronomic language and concerns. ${ }^{31}$ This is precisely the kind of activity we would expect in such an expanded text as $4 \mathrm{QRP}$, exegesis within the text, in this case by expansion, to bring it into agreement with contemporary practice (or ideal practice), rather than overt exegesis (i.e. lemma plus commentary). Thus, it once again seems most reasonable to argue from the simpler to the more complex: The Temple Scroll, a more thorough reworking of the Torah with a clear ideological bias, has borrowed material from the expansionistic 4QRP. ${ }^{32}$ Thus, we have two possible examples of the use of $4 \mathrm{QRP}$ as a source by pre-Qumranic compositions, leading to the conclusion that $4 \mathrm{QRP}$ was also composed prior to the settlement at Qumran.

27 For a detailed discussion of this parallel, see my article "Three Fragments from Qumran Cave 4 and their Relationship to the Temple Scroll," JQR 85 (1994) pp. 259-73.

28 As quoted by B. Z. Wacholder, The Dawn of Qumran (Cincinnati: Hebrew Union College, 1983) pp. 205-206.

29 H. Stegemann, "The Literary Composition," p. 135.

30 M. Wise, A Critical Study pp. 58-59.

31 M. Wise, A Critical Study pp. 48-50.

32 Of course, one could argue, as also in the Jubilees example, that both were drawing on a common source. That source, however, is hypothetical. See M. Wise, A Critical Study, chap. 2. 
4QReworked Pentateuch, the Temple Scroll, and Jubilees form a constellation of texts preserved by the Qumran community. All three are closely related to the Torah, $4 \mathrm{QRP}$ as the product of scribal intervention for the purpose of exegesis, the Temple Scroll and Jubilees as more thorough reworkings with theological agendas. All three also present themselves as authoritative texts: $4 \mathrm{QRP}$ gives no indication that it is not a regular Torah text, carrying with it Mosaic authority; Jubilees claims to have been dictated to Moses by an Angel of the Presence, and the Temple Scroll presents God speaking in the first person to Moses. They bear more in common as well: $4 \mathrm{QRP}$ and the Temple Scroll both mention the Fresh Oil festival and the Wood festival in their legal sections, while the 364-day solar calendar advocated by Jubilees is presupposed by the Temple Scroll. ${ }^{33}$ Finally, as stated above, it is possible that both the Temple Scroll and Jubilees draw on $4 Q R P$ as a source. As Vanderkam has stated concerning Jubilees and the Temple Scroll, "the authors of the two are drawing upon the same exegetical, cultic tradition." 34 To these two texts, I would add $4 \mathrm{QRP}$. This common tradition, evidenced by three major texts found at Qumran but not composed there, is further evidence that the manuscripts from Qumran are neither eclectic, with no principal of selection, nor sectarian, reflecting the interests of an isolated, "fringe" group of Jews from the late Second Temple period, but a collection, drawn from the vast and previously unknown literature of the Second Temple period, which reflects the theological tendency of a particular group, some of whom at least resided at Qumran during the Second Temple period. ${ }^{35}$

33 J. VanderKam, "The Temple Scroll and the Book of Jubilees," in Temple Scroll Studies, G. Brooke, ed. (Sheffield: JSOT Press, 1989) p. 216.

34 J. VanderKam, "The Temple Scroll and the Book of Jubilees," p. 232.

35 See now Gabriele Boccaccini and his thesis concerning Enochic Judaism and the Essenes. 
This kind of textual work demonstrates the major trend in Qumran textual studies today, a trend that goes hand-inhand with the reevaluation of the archaeological evidence from Qumran. Together, the two disciplines of textual studies and archaeology can work to form a new synthesis in Dead Sea Scrolls studies, which will carry us forward into the twenty-first century. 